\title{
Development of Virtual World Risk Perception Scale (VWRPS)
}

\author{
Veysel Bilal ARSLANKARA*a, Ertuğrul USTA ${ }^{\mathrm{b}}$
}

\begin{tabular}{l} 
Article Info \\
\hline DOI: $10.14686 /$ buefad.356898 \\
\hline Article History: \\
Received $\quad 22.11 .2017$ \\
Revised $\quad 07.02 .2018$ \\
Accepted $\quad 09.02 .2018$ \\
\hline Keywords: \\
The virtual world, \\
Risk perception, \\
Scale development. \\
\hline Article Type: \\
Research Article \\
\end{tabular}

\begin{abstract}
The aim of this study is to develop a valid and reliable scale to identify the risk situations perceived by high school students in different high schools in the context of virtual environments (social media, virtual networks), which are important in the field of Information Technologies. By examining the studies in domestic and foreign literature, more than 250 precursors were prepared and 34 items were determined by grouping and transforming into scale expression. The scale was applied to 390 high school students in various high schools in the academic year of 2016-2017. Twenty-six items were collected with five factorial factors and sufficient factor loadings (> .40) as the result of the exploratory factor analysis. The validity of the construct validity study, which measures a general structure (virtual risk perception) and five sub-dimensions named by experts (virtual corruption, virtual depreciation, virtual possibility, virtual opportunity and virtual awareness). Cronbach Alpha, Guttmann Split Half and Sperman Brown values were calculated for the reliability of the whole scale and subscales. As a result, it is expected that the Virtual World Risk Perception Scale (VWRPS), which is composed of five sub-factors and 26 items, is determined to be valid and reliable on the basis of the analyzes made, is a scale that is open to development, usable and filling the void.
\end{abstract}

\section{Sanal Dünya Risk Algısı Ölçeği (SDRAÖ)'nin Geliștirilmesi}

\begin{tabular}{|c|c|}
\hline \multicolumn{2}{|c|}{ Makale Bilgisi } \\
\hline DOI: 10.1 & 86/buefad.356898 \\
\hline $\begin{array}{l}\text { Makale Ge } \\
\text { Geliş } \\
\text { Düzeltme } \\
\text { Kabul }\end{array}$ & $\begin{array}{l}\text { mişi: } \\
22.11 .2017 \\
07.02 .2018 \\
09.02 .2018\end{array}$ \\
\hline \multicolumn{2}{|c|}{$\begin{array}{l}\text { Anahtar Kelimeler: } \\
\text { Sanal dünya, } \\
\text { Risk algısı, } \\
\text { Ölçek geliştirme. }\end{array}$} \\
\hline \multicolumn{2}{|c|}{$\begin{array}{l}\text { Makale Türü: } \\
\text { Araştırma Makalesi }\end{array}$} \\
\hline
\end{tabular}

\section{Öz}

$\mathrm{Bu}$ çalışmanın amacı, Bilişim Teknolojileri alanında önemli yer tutan sanal ortamlar (sosyal medya, sanal ağlar) çerçevesinde farklı liselerde öğrenim gören lise öğrencilerinin bu ortamlara ilişkin algılamış oldukları risk durumlarını tespit etmek amacıyla geçerli ve güvenilir bir ölçek geliştirmektir. Yerli ve yabancı alanyazında yer alan çalışmaların incelenmesiyle 250'nin üzerinde öncül madde hazırlanarak gruplandırma ve ölçek ifadesine dönüștürme ișlemi yapılmış ve 34 madde belirlenmiştir. Ölçek çeşitli liselerde öğrenim gören 390 lise öğrencisine 2016-2017 eğitim öğretim yılında uygulanmıştır. Açımlayıcı Faktör Analizi neticesinde 5 faktörde toplanan ve faktörlerde yeterli faktör yüküne (>.40) sahip 26 madde seçilmiştir. Elde edilen 26 maddelik ölçeğin bir genel yapısı (sanal risk algısı) ve uzmanlar tarafından isimlendirilen beş alt boyutu (sanal yozlaşma, sanal yıpranma (çöküntü), sanal olanak, sanal firsat ve sanal farkındalık) ölçüp ölçmediğine ilişkin yapı geçerliği çalışması Doğrulayıcı Faktör Analizi ile gerçekleştirilmiştir. Ölçeğin tamamı ve alt boyutların güvenirlikleri için Cronbach Alpha, Guttmann Split Half ve Sperman Brown değerleri hesaplanmıştır. Neticede beş alt faktör ve 26 maddeden oluşan ve yapılan analizler neticesinde geçerli ve güvenilir olduğuna karar verilen Sanal Dünya Risk Algısı Ölçeği (SDRAÖ)'nin, geliştirilmeye açık, kullanılabilir düzeyde ve ilgili alanyazında boşluğu dolduran bir ölçek olması beklenmektedir.

\footnotetext{
*Corresponding Author: vbilalarslankara@gmail.com

${ }^{\text {a }}$ ICT Teacher, Tutak Vocational and Technical Anatolian High School, Agri/Turkey, http://orcid.org/0000-0002-9062-9210

b Assoc. Prof. Dr., Necmettin Erbakan University, Konya/Turkey, http://orcid.org/0000-0001-6112-9965
} 


\section{Introduction}

While defining the age we live in, definitions are made under the name of information, communication, internet age or information society. With the development of technology, the rapid development in information communication technologies and the widespread use of change and use in almost all fields have offered many opportunities for individuals, besides bringing many radical changes from political habits to basic life habits in social life as well as individual life, it also revealed some problems with it. The unpleasant situation and events that are detected in the researches carried out on this subject or presented in the media, such as internet, mobile phone, etc. the negative use of information communication tools is also a tool for many problems, such as debate and fighting that can result in death in addition to experiencing depression and mental depression in a simple sense. As a matter of fact, in this context, adolescents in high school ages called adolescents have common (problematic) internet use, internet addiction, cyber bullying, it is becoming commonplace to face risks.

The unlimited internet network offered on the world and the unlimited use of opportunities (network, tools, etc.) offered by mobile phones, which are the main elements of our lives today, are also a source of problems faced by administrators and teachers in educational institutions today.

Information-communication and information technology; e-government, e-education, e-communication, ecommerce, and many other areas are open to use by individuals of all ages and levels. It is inevitable that the diversification and widespread use of these tools and services offered to the individuals by these developing technologies naturally bring various problem areas together. This can be expressed as inappropriate use of information technologies, which can be considered as the most general and basic conceptual heading of these problems. These improper uses cause the growth of an addicted population to the international arena as spiritual wear; it should be considered as a negative result in a wide range of people, from madden to depression, by creating a society that is capable of handling cyber mistakes at any moment and processing information crimes. Studies conducted in Turkey also reveal that many cybercriminals are involved in our society, from cyber fraud to e-mail threats and indignities (Beyhan, 2002).

In addition to the criminal context, it should be taken into consideration that these technologies expressed in the dimension of the health dimension can come from physical (Özcan, Esmaeizadeh and Bölükbaş, 2007) or psychological / psychiatric disorders (Arısoy, 2009) resulting from excessive, unbalanced and unplanned use. SMS, blogs; Whatsapp, Telegram application; forums etc. Unlimited and unplanned use of the tools at any time and anywhere, inclusion in chat rooms, sharing of all kinds of information, documents, images and videos in social environments (Facebook, Twitter, Flickr, Instagram, Snapchat etc.) the use of many different tools and facilities in a widespread and uncomfortable manner at all levels has led to the inclusion of a concept such as the "virtual risk perception" (virtual world risk perception) in the literature; but the virtual risk perception that we have expressed should not be seen as a totally independent, irrelevant concept from the traditional risk perception. The virtual risk perception can be regarded as a form of traditional risk perception or as a new form of traditional risk perception.

As is the case in all the countries of the world, the use of the tools provided by the information technology in our country is increasing proportionally and it is becoming a serious place in our lives by diversification. According to the results of "Use of Household Computing Technologies" survey conducted by the Turkish Statistical Institute (TSI) in 2017, it was observed that the use of computers and internet continued to increase at all levels without slowing down. In the study conducted, it was found that $54,9 \%$ and $61,2 \%$ of the computer and internet usage rates of the individuals in the 16-74 age groups in 2016 were; When it comes to 2017, the rate of computer and internet usage in the age group of $16-74$ years is $56,6 \%$ and $66,8 \%$ respectively (TSI 2017).

It is an undeniable fact that these technologies have become an indispensable element for the students in the direction of various purposes as well as the individual accessibility of these technologies with the use of computerized technologies and internet, as well as the inclusion of education and training processes in educational institutions. These losses, which may arise as a result of the use of all related technologies in this respect, are also important threats and threats for adolescents, especially those who continue their physical and mental development.

Internet addiction in our age when computers and mobile phones are no longer referred to as the Internet or not, and psychological pressure on the internet, especially on sharing platforms, are also emerging in the school age as problem areas based on virtual risk perception information technologies with another expression of abusive behaviour. The necessity of internet dependence is to be examined in our social processes based on the virtual risk perception, the widespread use of technology and the declining age of use. Considering the recent studies, internet 
addiction (Ayas, 2012; Bilge, 2012; Ceyhan, 2011; Ekşi, 2012) and cyberbullying (Arıcak, 2009; Baker Erdur and Kavsut, F., 2007, Çetin, Eroğlu, Peker, Akbaba and Pepsoy, 2012; Özdemir and Akar, 2011; Yaman and Peker, 2012) are diversified and increased depending on the importance of the subject.

It was decided by the Turkish Grand National Assembly (TGNA) that the impact of such Internet use on younger individuals was important, and a parliamentary research commission was set up in 2012. While many different influences of the internet were taken into consideration in the report prepared by the research commission (TGNA, 2012), the internet dependency and cyberbullying were also included in these dimensions. In the context of the educational need to look at this rapport, which the parliamentary research commission has written, "Work to make early manifestations of Internet addiction and problematic internet use visible in the family or school"; Including "research at the national level on problematic use of the Internet".

In the TSI (2017b) report, it is stated that the age group with the highest computer and internet usage rates is the group between 06-15. In this research, it was aimed to question the internet addiction and the situation of cyberbullying in the middle school age by aiming at lower age groups than the highest usage rates of this age group. Based on the results of our research in our country and the conclusions and suggestions of the parliamentary research commission, the problem of this research is that students in the middle school age are not aware of internet addiction and bullying situations.

\section{Purpose of the study}

This research aims to provide a research tool that can be done on the perceived risk (threat / opportunity) in the virtual world by examining the risk perceptions felt by high school students in the virtual environment at individual level by developing the likelihood perception scale in the virtual environment and developing a likert type perception scale in the context of high school students, to determine. It is also to determine what dimensions the Virtual World Risk Perception Scale (VWRPS) deals with in relation to the virtual world and virtual environments.

The answer to the following question will be searched in this frame:

- Is the scale developed to determine perceived risks (virtual world risk perception) of existing high school students in the virtual world (in virtual environments), Facebook, Snapchat, Twitter, Instagram etc.?

\section{Method}

\section{Research Model}

The purpose of this study was to develop a scale called the Virtual World Risk Perception Scale, to examine its validity and reliability. The required data were collected from the individuals in the study group identified as the target mass of the study using the measurement tool.

\section{Universe and Sampling}

The universe of this research is the official secondary education institutions within the borders of Ağr1 province. Factor analysis and reliability studies in the study were conducted with the data obtained from 390 high school students (176 girls, 214 males) in different high schools (Vocational High School, Technical High School, Anatolian High School, Imam Hatip High School) in Ağrı. There are 34 items in the substance pool in practice. It is recommended that scale participants have access to 5 to 10 times the number of items in the item pool. Comrey and Lee (1992) described that 100 samples are of a weak level, 200 are moderate, 300 is good, 500 is very good, and 1000 is excellent. Therefore, this number is sufficient for the application. However, in order to ensure diversity at a high level in the working group, it was preferred to reach school students in different fields. Of these students, 63 (16.2\%) are Vocational High School, 252 (64.2\%) are Anatolian High School and 75 (19.2) are Technical High School students. The convenience sampling method was applied when working groups were created. The distribution of the study group by schools, class levels and genders is summarized in Table 1. 
Table 1. School-Class Level-Gender Distribution of the Working Group

\begin{tabular}{lcc}
\hline \hline \multicolumn{1}{c}{ Değişkenler } & Frekans (n) & Yüzde (\%) \\
\hline Vocational High School & 63 & $16.2 \%$ \\
Anatolian High School & 252 & $64.6 \%$ \\
Technical High School & 75 & $19.2 \%$ \\
\hline & & \\
9th grade & 120 & $30.8 \%$ \\
10th grade & 136 & $34.9 \%$ \\
11th grade & 76 & $19.5 \%$ \\
12th grade & 58 & $14.9 \%$ \\
& & \\
Female & 176 & $45.1 \%$ \\
Male & 214 & $54.9 \%$ \\
\hline \hline
\end{tabular}

\section{Data Collection Tools-Analysing Data}

Data were collected using the "Virtual World Risk Perception Scale (VWRPS)" developed by the researchers. In the process of developing the scale, primarily local and foreign literature searches were carried out. However, no measurement tool has been found to measure the concept of "risk" previously in virtual environments. As a result of the literature survey, it has been tried to determine the characteristics of the virtual world (virtual environments). The theoretical framework of your scale was developed based on the concept of risk, which involves the threat / opportunity and opportunities that exist in virtual environments in the use of technology. A 64-point pool was created from the data written in the light of the examinations. Among the items, the characteristics of the target kits to be used by the measurement tool were determined and a 40 -item draft was created by grouping the items targeting the nearest features. In order to ensure coverage, the draft articles were presented to the lecturers of the Departments of Computer Education and Instructional Technology and the Psychological Counselling and Guidance Department working in different universities, and 34 items were determined as scale expressions for determining the risk perceptions of the high school students regarding the virtual world. For the validity of the scale, a specialist teacher working as a Turkish Teacher in the Ministry of National Education has determined the suitability of the language of the materials on the scale for the target audience in terms of "intelligibility" and "grammar".

Of the scales, 31 were positive and 3 were negative. Then, in a small group of 10 people, it was asked to define a 5-point Likert-type scale consisting of 34 items in order to make students' opinions about perception of risk dimension by virtual environments. The answers that the students gave to the positive items were scored as follows: Totally reflecting (5 points), very reflecting ( 4 points), moderately reflecting ( 3 points), less reflecting ( 2 points), and not reflecting at all (1 point). Students' responses to negative design items were inversely scored and reversecoded in the statistical analysis process.

The lowest score that can be taken from the scale is 34 while the highest score is 170 . The high scores indicate that the level of risk perception related to the virtual world is also high. The final scale was multiplied and applied to 390 high school students. The obtained data were statistically coded in accordance with the SPSS 23.0 and AMOS 24.0 programs in order to conduct validity and reliability analyses of the scale.

Reliability analysis was first performed on the collected data. The reliability coefficient Cronbach alpha coefficient $\alpha=0.88$ was found. The reliability of your scale is high, so it is suitable for analysing for scale validity. In order to determine the validity of the scale, Kaiser-Meyer-Olkin (KMO) and Bartlett analyses were performed to determine whether factor analysis would be performed or not (Tavşanc1l, 2006). It is interpreted that the KMO 
value exceeding .90 is the perfect level for the factor analysis of the data set. However, according to the Bartlett test values, it is understood that the null hypothesis is rejected at a significance level of 0.05. Explanatory and confirmatory factor analyses were made on data at the end of the obtained values; the separation of the factors to the scale was determined by the analysis of the basic components;

Factor analysis is conducted to determine if a developed metric is divided into fewer dimensions. For this reason, analysis of the basic components is also used as a method of separation of factors. In this context, factor loadings were investigated using Promax oblique rotation technique because it was considered that there was a relationship between factors due to high reliability (Erkuş, 2003). The oblivious rotation technique is based on the assumption that the factors are related to each other. In contrast to the orthogonal rotation, different axes are used to rotate the axes. Factors greater than 1.00 were assessed and factors that should be excluded from analysis according to the results obtained were subtracted from the scale, and factor analysis studies were repeated until definite results were obtained with net values $($ Kappa =4) (Çokluk, Şekercioğlu and Büyüköztürk, 2010).

Verifiable Factor Analysis was applied on the same data structure to prove the validity of the 5 factorial design determined by the Promax Rotation Method and the extent to which the observed structure was compatible with the data. In order to evaluate the validity of the model in DFA, Chi-square fit test (X2), mean square error (RMSEA), comparative fit index (CFI), goodness of fit index (GFI), corrected goodness of fit index (AGFI) (NFI) and standardized goodness of fit index (SRMR). The acceptability criteria for these values are stated as follows: It is accepted that the ratio of X2 / sd expressed as the normed chi-square is less than 3 (Y1lmaz and Çelik, 2009, Şimşek 2007). A good fit of RMSEA and SRMR values of less than or equal to .05 and a good fit of between .05 and .08 (Yilmaz and Celik, 2009, Simsek 2007). It is accepted that the GFI and CFI values are higher than .90 and the AGFI value is higher than .85 (Y1lmaz and Çelik, 2009). The reliability of the 5 factors and the 26-item scale, which were obtained as a result of all analyzes, were examined according to Cronbach Alpha, Guttmann Split Half and Sperman Brown reliability coefficients.

\section{Findings}

The structural validity, item-total correlations and item discrimination were examined in the framework of the Virtual World Risk Perception Scale (VWRPS). In the context of reliability, the internal consistency coefficient Cronbach alpha value was examined on the data and the findings obtained by the performed procedures are as follows:

\section{Findings related to scale validity}

The structure of the scale was examined based on valid factor analysis, item total correlations and item discriminants. According to Tavşancıl (2002), the item test correlations for the items in the scale are found to be .30 and above. However, transactions should be carried out in consideration of the fact that the materials are not connected to more than one factor. The criterion for having more than one factor is that there is a minimum difference of .10 between factor loads. Chi-Hwang and Henry (1990), Yavuz (2005) and Tsai and Chai (2005) found that items with factor loadings below .40 were drawn from the scale. However, Büyüköztürk (2007) stated that factor loads greater than .45 would be an important criterion for the selection of scales. For this reason, in this study, the total correlations of the items are based on the assumption that the items with less than .30 and the items with less than .10 are subtracted from the scale between the items with factor load values less than .40 and the related items.

\section{Results of exploratory factor analysis:}

In order to test the validity of VWRPS, KMO and Bartlett tests were first performed on the data and KMO = .922; Bartlett value is $\mathrm{X} 2=4627,412$; $\mathrm{sd}=561(\mathrm{p}=.000)$. As a result of these values, it is proved that factor analysis can be performed on the 34-item scale and that the data come from the widely distributed normal distribution. Factor analysis was performed on the scale 4 times for the detection of the items in the measurement and the elimination of the items under the factor load value of .40. The content of the steps applied in this process is as follows: During the first factor analysis phase, 7 factors with eigenvalues greater than 1 were obtained as a result of the basic component factor analysis using Promax oblique rotation technique. These 7 factors account for $54.72 \%$ of the total variance. The total correlations of the items from the 34 items in this phase are between .30 and $.70 .9,12,15$, and 16. Because the factor loadings of the items were below .40, they were removed from the scale. It has been determined that the 27 th substance is removed from the scale due to the fact that it is a contaminant substance. Factor analysis was applied on the remaining 29 items. Based on the results of the second 
factor analysis, 6 factors with a scale factor greater than 1 were collected, and these 6 factors account for $50.06 \%$ of the total variance. The total item correlations of the second stage items are between 30 and 61 . At this stage, the 18th, 20th and 30th items with a factor load of less than .40 are not included in the next analysis. According to the results of the third factor analysis, the scale is aggregated under 5 factors which are larger than 1 . These 5 factors explain $51.72 \%$ of the total variance. At this stage, item total correlations were between .30 and .58 .

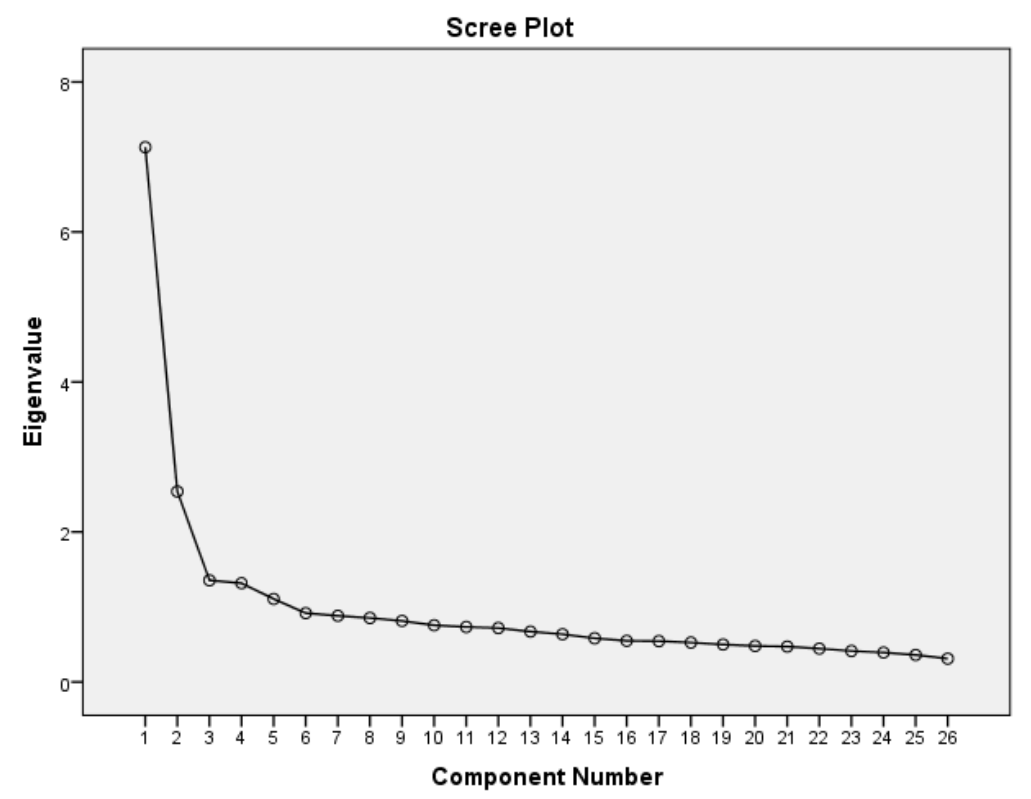

Figure 1. Line graph of the eigenvalues

As can be seen in the line graph of the eigenvalues in Figure 1, it is understood from the line graph of the eigenvalues that the scale is collected under the factor of 5. In the graph, a high acceleration decline after the first factor indicates that the scale has a general factor. After the fifth factor, the overall trend of your graph is horizontal and there is no significant downward trend.

Table 2. School-Class Level-Gender Distribution of the Working Group

\begin{tabular}{|c|c|c|c|c|c|c|c|c|}
\hline \multirow{2}{*}{$\begin{array}{l}\text { Article } \\
\text { No }\end{array}$} & \multirow{2}{*}{$\begin{array}{c}\text { New } \\
\text { Queue } \\
\text { No }\end{array}$} & \multirow{2}{*}{$\begin{array}{c}\text { Factor } \\
\text { Load } \\
\text { Rating }\end{array}$} & \multicolumn{5}{|c|}{ Rotated Factor Load Values } & \multirow{2}{*}{$\begin{array}{c}\text { Item Total } \\
\text { Correlation } \\
\text { Values }\end{array}$} \\
\hline & & & Factor 1 & Factor 2 & Factor 3 & Factor 4 & Factor 5 & \\
\hline Md7 & 1 & .705 & .763 & & & & & .490 \\
\hline $\mathrm{Md} 2$ & 2 & .660 & .743 & & & & & .489 \\
\hline Md6 & 3 & .697 & .662 & & & & & .477 \\
\hline $\mathrm{Md} 3$ & 4 & .527 & .639 & & & & & .383 \\
\hline Md8 & 5 & .733 & .582 & & & & & .535 \\
\hline Md1 & 6 & .546 & .537 & & & & & .449 \\
\hline Md5 & 7 & .552 & -.501 & & & & & .497 \\
\hline $\operatorname{Md} 32$ & 8 & .606 & & .796 & & & & .459 \\
\hline $\operatorname{Md} 33$ & 9 & .614 & & .756 & & & & .477 \\
\hline $\operatorname{Md} 28$ & 10 & .643 & & .627 & & & & .543 \\
\hline $\operatorname{Md} 17$ & 11 & .707 & & .550 & & & & .589 \\
\hline $\mathrm{Md} 21$ & 12 & .654 & & .536 & & & & .510 \\
\hline
\end{tabular}




\begin{tabular}{|c|c|c|c|c|c|c|c|c|}
\hline $\operatorname{Md} 22$ & 13 & .591 & & .432 & & & & .485 \\
\hline Md34 & 14 & .575 & & & .783 & & & .395 \\
\hline $\operatorname{Md} 26$ & 15 & .639 & & & .726 & & & .403 \\
\hline $\operatorname{Md} 25$ & 16 & .665 & & & .627 & & & .428 \\
\hline $\operatorname{Md} 24$ & 17 & .485 & & & .495 & & & .428 \\
\hline Md10 & 18 & .546 & & & & -.842 & & .407 \\
\hline Md11 & 19 & .536 & & & & .629 & & .403 \\
\hline Md4 & 20 & .350 & & & & -.507 & & .306 \\
\hline $\operatorname{Md} 29$ & 21 & .694 & & & & .492 & & .461 \\
\hline Md31 & 22 & .613 & & & & .472 & & .391 \\
\hline $\operatorname{Md} 23$ & 23 & .591 & & & & & .693 & .417 \\
\hline Md13 & 24 & .483 & & & & & .580 & .402 \\
\hline Md19 & 25 & .580 & & & & & .571 & .327 \\
\hline Md14 & 26 & .533 & & & & & .483 & .355 \\
\hline \multicolumn{3}{|c|}{ The eigenvalues } & 7.130 & 2.539 & 1.355 & 1.316 & 1.107 & \\
\hline \multicolumn{3}{|c|}{ Variance Ratio Explained } & 27.423 & 9.767 & 5.212 & 5.062 & 4.257 & \\
\hline \multicolumn{3}{|c|}{$\begin{array}{c}\text { The total variance ratio declared } \\
\text { for the scale }\end{array}$} & \multicolumn{6}{|c|}{51.721} \\
\hline \multicolumn{3}{|c|}{ Cronbach Alpha } & $\alpha=.63$ & $\alpha=.80$ & $\alpha=.68$ & $\alpha=.69$ & $\alpha=.63$ & \\
\hline \multicolumn{3}{|c|}{$\begin{array}{c}\text { For the whole scale, Cronbach } \\
\text { Alpha }\end{array}$} & \multicolumn{6}{|c|}{$\alpha=.82$} \\
\hline
\end{tabular}

As seen in Table 2, 5 factors in the final measure are $51.72 \%$ of the scale variance. The item correlation of the scale is between .33 and .59. There is no material in the scale. Factor load values range from .40 to .61. The 26item scale is included in Appendix 1. Factor nomenclature was determined in the light of literature review. Factor 1 items "Virtual Corruption", Factor 2 items "Virtual Collapse", Factor 3 items "Virtual Offer", Factor 4 Elements "Virtual Facility" and Factor 5 Elements "Virtual Awareness".

\section{Confirmatory factor analysis results:}

Confirmatory Factor Analysis (CFA) is a frequently used method of analysis in the development of measurement models. This method is a factor analysis that utilizes the factors determined by Explanatory Factor Analysis (AFA) through a pre-established model to test the appropriateness to the determined factor structures. The AFA uses DFA to test which groups of substances are highly related to which factor, and to determine whether groups of substances associated with a given number of factors are adequately represented by these factors.

In this context, as a result of confirmatory factor analysis using maximum likelihood technique, goodness of fit values; $\mathrm{KF} / \mathrm{RF}=2.047, \mathrm{X} 2=591.496, \mathrm{p}<.000, \mathrm{RMSEA}=.052, \mathrm{~S}-\mathrm{RMR}=.124, \mathrm{GFI}=.90, \mathrm{AGFI}=.88, \mathrm{CFI}$ $=.89, \mathrm{NFI}=.81$ and $\mathrm{IFI}=.90$ respectively. According to these values, all good values are acceptable values (Munro, 2005; Schreiber, Nora, Stage, Barlow and King, 2006). Therefore, this model implies that the factors are confirmed by the data. The factorial model of the scale and the t-values showing the factor-substance relationship are given in Fig. 


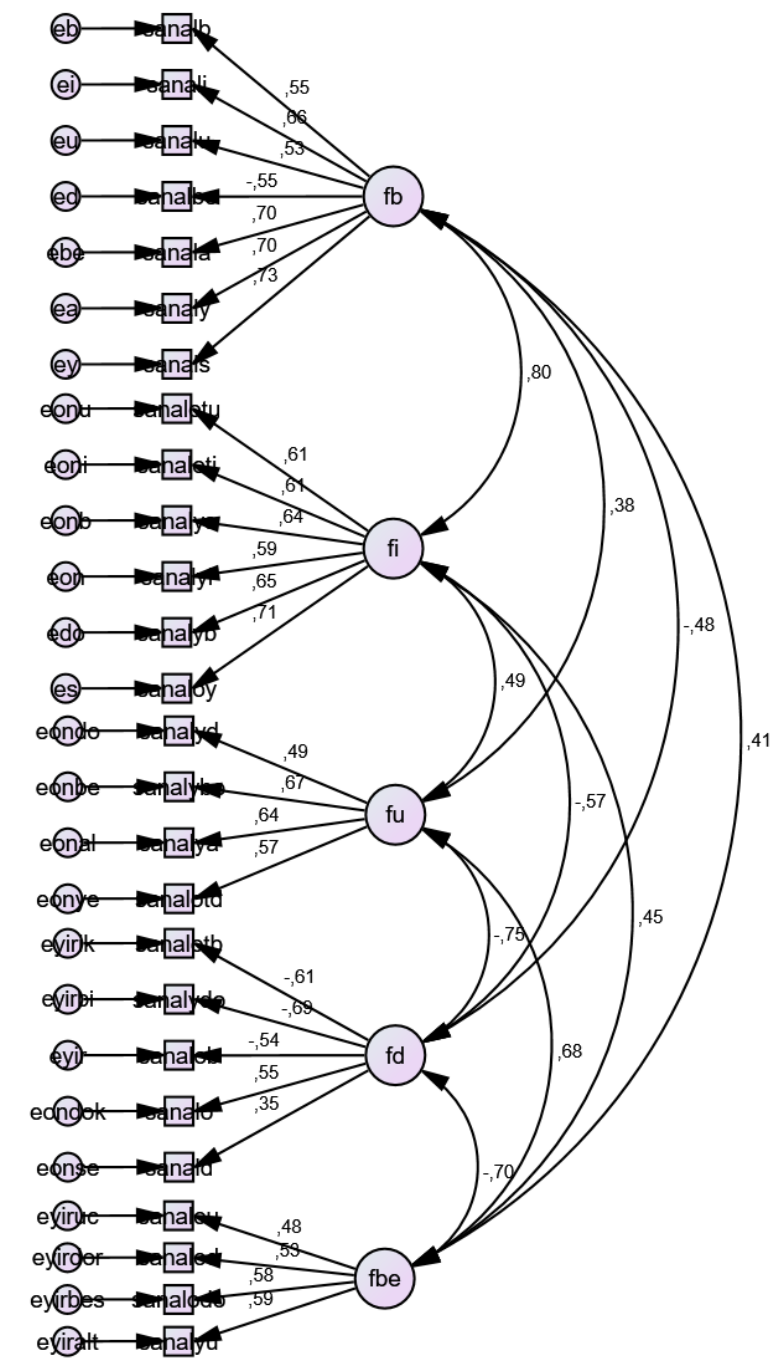

Figure 2. First-level confirmatory factor analysis correlation diagram (Standardized values)

\section{Findings related to scale reliability}

An internal consistency analysis was performed on the data to calculate the reliability of the scale. The processes and findings are as follows.

Reliability according to the factors to be measured and as a whole; Cronbach alpha, Sperman-Brown formula and Guttmann Split-Half reliability formulas. The results of the reliability analysis of the factors and the overall scale are given in Table 3: 
Table 3. Internal consistency levels

\begin{tabular}{lcccc}
\hline Factors & $\begin{array}{c}\text { Article } \\
\text { Numbers }\end{array}$ & $\begin{array}{c}\text { Cronbach } \\
\text { Alpha }\end{array}$ & $\begin{array}{c}\text { Sperman } \\
\text { Brown }\end{array}$ & $\begin{array}{c}\text { Guttmann } \\
\text { Split Half }\end{array}$ \\
\hline $\begin{array}{l}\text { F1 - Virtual } \\
\text { Corruption }\end{array}$ & 7 & .63 & .66 & .65 \\
\hline $\begin{array}{l}\text { F2 - Virtual } \\
\text { Fraying }\end{array}$ & 6 & .80 & .76 & .75 \\
\hline $\begin{array}{l}\text { F3 - Virtual } \\
\text { Offer }\end{array}$ & 4 & .68 & .67 & .67 \\
\hline $\begin{array}{l}\text { F4 - Virtual } \\
\text { Facility }\end{array}$ & 5 & .69 & .57 & .56 \\
\hline $\begin{array}{l}\text { F5 - Virtual } \\
\text { Awareness }\end{array}$ & 4 & .63 & .64 & .64 \\
\hline Total & $\mathbf{2 6}$ & $\mathbf{. 8 2}$ & $\mathbf{. 7 2}$ & $\mathbf{. 8 6}$ \\
\hline
\end{tabular}

\section{Discussion and Conclusion}

In this research especially Facebook, Instagram, Twitter and so on. The Virtual World Risk Perception Scale (VWRPS) was developed to determine the levels of risk present in virtual environments. The developed VWRP is a scale of five likert type and consists of 26 items, which are formed under 5 factors. Substances included in the factors; It is scaled so that it reveals to what extent the individual on the scale reflects his / her own perception with the expressions "totally reflecting", "highly reflecting", "reflecting at moderate", "rarely reflecting" and "reflecting at all". 9-12.390 students were enrolled in the class.

Factor analysis was carried out within the scope of validity studies of the scale. Factor analysis on the scale study was deemed appropriate according to the values of KMO and Bartlett tests $(\mathrm{BMD}=.922$, Bartlett $=$ $3099,284, \mathrm{p}=.000$ ). Firstly, with the Explicit Factor Analysis (AFA), it was tested how many factors were separated by the scale, whether the factors explained more than $40 \%$ of the variance, and which loads and which factors were distributed. In this context, Principal component is extracted and promax $(\mathrm{kappa}=4)$ oblique rotation technique is used as the rotation technique because of its high reliability. It was seen that in the result of AFA, the scale had 5 factors and the factors explained $51.72 \%$ of the total variance. It has been adopted that the threshold value is above .40 while the distribution with factor loads is determined. In the result of Confirmatory Factor Analysis performed after AFA, it was determined that the distributed factor items support AFA and that DFA values (X2 / sd, p, RMSEA, S-RMR, GFI, AGFI, CFI, NFI, IFI) and factor naming were done in the context of the relevant literature. In order to provide scope validity and appearance validity, scope was presented to different field experts while the scale was still in the development stage and necessary arrangements were made in line with the opinions received to provide coverage, appearance and language validity. These results indicate that VWRP is valid.

Reliability of VWRP in terms of internal consistency was examined by calculating the reliability coefficients of Cronbach Alpha, Guttmann Split Half and Sperman Brown. The reliability coefficients of Cronbach Alpha, Guttmann Split Half and Sperman Brown of the combined scale were calculated as .82, .72 and .86, respectively, and it was concluded that the reliability levels were very good.

Suggestions developed for these results obtained without working are presented below.

- The Virtual World Risk Perception Scale (VWRPS) can provide valid and reliable scores with a combined scale and 5 sub-dimensions. For this reason, combined scale scores can be used to measure the perceived risk perception of the virtual world in general for high school students. In addition, sub-factor scores can be used to measure perceptions of the "virtual corruption", "virtual depreciation", "virtual ability", "virtual opportunity" and "virtual awareness" levels of high school students. 
- The scale was developed by studying the students in high school. It may be considered to study the students at these levels so that the scale can be used at secondary or university levels.

- Can work on test retest reliability and substance discrimination not done in this study.

- Depending on these results, it may be advisable for researchers, school administrators, teachers to use the SDRA when they work in order to take measures against virtual risk perceptions, depending on the extent to which the risk perceptions of the virtual world are related to the students' 


\title{
Sanal Dünya Risk Algısı Ölçeği (SDRAÖ)'nin Geliştirilmesi
}

\begin{abstract}
Giriş
Yaşadığımız çağın tanımı yapılırken bilgi, bilişim, iletişim, internet çağı ya da bilgi toplumu adı altında tanımlamalar yapılmaktadır. Teknolojinin gelişmesi ile birlikte bulunduğumuz çağın yakın dönemlerinde bilgi iletişim teknolojilerinde yaşanan hızlı gelişim ve değişim ile kullanımının hemen tüm alanlarda giderek yaygınlaşması bireylere birçok firsat sunmuş, gerek bireysel yaşam gerekse de toplumsal yaşamda temel düzeydeki alışkanlıklardan politik değişimlere değin birçok radikal değişimi getirmenin yanında alışılmış olan durumların haricinde beraberinde bazı sorunları da ortaya çıkarmıştır. Bu konu ile ilgili gerçekleştirilen araştırmalarda tespit edildiği ya da medyada sunulan nahoş durum ve olaylar internet, cep telefonu vb. bilişim iletişim araçlarının negatif yönde kullanımının, basit anlamda depresyona girip ruhi bunalım yaşatmanın yanında ölümle sonuçlanabilen tartışma ve kavgalara kadar birçok problemin de aracı olduğunu göstermektedir. Nitekim bu bağlamda ergen olarak isimlendirilen lise çağlarındaki gençlerin yaygın (problemli) internet kullanımı, internet bağımlılığı, siber zorbalık vb. risklerle karşı karşıya kalmaları sıradan bir hale gelmektedir.
\end{abstract}

Dünya üzerinde sunulan sınırsız internet ağı ve günümüzde hayatımızın başlıca unsuru haline gelen cep telefonlarının sunmuş olduğu firsatların (ăg, araç vb.) yaygın şekilde kontrolsüzce kullanılması, günümüzde eğitim kurumlarında idareci ve öğretmenlerin karşı karşıya kaldığı birtakım sorunun da kaynağı durumundadır.

Bilgi-iletişim ve bilişim teknolojileri; kurumsal bazda e-devlet, e-eğitim, e-haberleşme, e-ticaret gibi terimlerle adlandırılmakta ve sözü edilen bu terimlerin haricinde birçok farklı alanda her yaştan ve her seviyeden bireyin kullanımına açılmaktadır. Gelişen bu teknolojiler tarafindan bireylere sunulan bu araç ve hizmetlerin kullanımın bu derecede çeşitlenmesi ve yaygınlaşmasının çeşitli sorun alanlarını da doğal olarak beraberinde getirmesi kaçınılmazdır. Bilişim teknolojilerinin uygunsuz kullanımı olarak ifade edebileceğimiz bu durum bu sorunların başında gelen en genel ve en temel kavramsal başlık olarak ele alınabilir. Bu uygunsuz kullanımlar internete müptela bir toplumun yetişmesine neden olarak manevi yıpranmalara; her an siber hatalar işlemeye müsait bir toplum oluşturarak da bilişim suçlarının işlenmesine eden olup madden çöküntülere kadar geniş bir yelpazede olumsuz sonuçlar olarak değerlendirilmelidir. Türkiye'de de yapılan çalışmalar, sanal dolandırıcılıktan e-posta yoluyla tehdit ve hakarete kadar birçok bilişim suçunun toplumumuzda yer aldığını ortaya koymaktadır (Beyhan, 2002).

Suç bağlamının haricinde düşünüldüğünde ise -sağlık boyutunda- ifade edilen bu teknolojilerinin aşırı, dengesiz ve plansız kullanımından kaynaklanan gerek fiziksel (Özcan, Esmaeizadeh ve Bölükbaş, 2007) gerekse de psikolojik/psikiyatrik rahatsızlıkların (Arısoy, 2009) meydana gelebileceğinin de göz önünde bulundurulması gerekmektedir. SMS, Bloglar; Whatsapp, Telegram uygulaması; forumlar vb. Araçların her an her yerde sınırsız ve plansız şekilde kullanımı, Sohbet (Chat) odalarına dahil olma, sosyal ortamların (Facebook, Twitter, Flickr, Instagram, Snapchat vs.) her türlü bilgi, belge, görüntü ve video paylaşımına olanak tanıması, bunun yanında daha birçok farklı araç ve imkânın yaygın bir şekilde her düzeyde, rahatsız edici şekilde kullanılması "sanal risk algısı (sanal dünya risk algıs1)" gibi bir kavramın literatüre dahil olmasına neden olmuştur; Ancak ifade ettiğimiz sanal risk algısı, geleneksel risk algısından tamamen bağımsız, ilgisiz bir kavram olarak görülmemelidir. Sanal risk algısı, geleneksel risk algısı ile ilişkisi bir tür ya da geleneksel risk algısının yeni bir biçimi olarak kabul edilebilir.

Tüm dünya ülkelerinde olduğu gibi ülkemizde de bilişim teknolojilerinin sunduğu araçların kullanımı oransal olarak artış göstermekte ve git gide çeşitlenerek hayatımızda ciddi bir yer edinmektedir. Türkiye İstatistik Kurumu (TÜIK)'nun 2017 yılında yapmış olduğu "Hanehalkı Bilişim Teknolojileri Kullanım Araştırması" sonuçlarına göre bilgisayar ve internet kullanımının hız kesmeden tüm seviyelerde artmaya devam ettiği görülmüştür. Yapılan çalışmada 2016 yılında 16-74 yaş gruplarında yer alan bireylerin bilgisayar ve internet kullanım oranlarının \%54.9 ve \%61.2 olduğu ancak; 2017 yllına gelindiğinde ise 16-74 yaş grubundaki bireylerde bilgisayar ve internet kullanım oranlarının sırasıyla \%56.6 ve \%66.8 gibi oranlara yükseldiği ele alınmaktadır (TÜIK 2017a).

Bilgisayarlı teknolojilerin ve internet kullanımı ile bu teknolojilere ulaşılabilirliğin bireysel olarak artmasının yanında eğitim kurumlarında da eğitim öğretim süreçlerini destekleyici olarak bu sürece dahil edilmesiyle bu teknolojilerin çeşitli amaçlar doğrultusunda öğrenciler için de vazgeçilmez bir unsur haline geldiği yadsınamaz bir gerçektir. Bu yönde ilgili tüm teknolojilerin kullanımı neticesinde ortaya çıkabilecek bu zararlar özellikle fiziksel ve zihinsel gelişimlerini sürdürmekte olan ergenler için de önemli birer tehdit ve tehlike unsuru olmaktadır.

Bilgisayarların ve cep telefonlarının artık internetsiz olarak anılmadığı veya anlamlandırılmadığı çağımızda internet bağımlılı̆̆ı ve internet üzerinde özellikle paylaşım platformlarında hissedilen psikolojik baskı gibi insan zihnini taciz edici davranışlar diğer bir ifadesiyle sanal risk algısı bilişim teknolojilerine dayalı sorun alanları olarak okul çağındaki bireylerde de ortaya çıkmaktadır. Gerek internet bağımlılığı gerekse sanal risk algısı, teknolojinin yaygınlaşması ve kullanım yaşının düşmesine dayalı olarak toplumsal süreçlerimizde incelenmesi gereken konular olmayı gerektirmektedir. Son zamanlarda yapılan çalışmalar dikkate alındığında internet 
bağıml1lığı (Ayas, 2012; Bilge, 2012; Ceyhan, 2011; Ekşi, 2012) ve siber zorbalık (Arıcak, 2009; Baker Erdur ve Kavşut, F., 2007; Çetin, Eroğlu, Peker, Akbaba ve Pepsoy, 2012; Özdemir ve Akar, 2011; Yaman ve Peker, 2012) konularındaki çalışmaların konunun önemine bağlı olarak çeşitlendiği ve arttığı gözlemlenmektedir.

Türkiye Büyük Millet Meclisi (TBMM) tarafından bu tür internet kullanımının genç yaştaki bireyler üzerindeki etkisi önemli görülerek 2012 yılında bir meclis araştırma komisyonu kurulmasına karar verilmiştir. Kurulan araştırma komisyonunun hazırladığı raporda (TBMM, 2012) internetin birçok farklı etkisi göz önünde bulundurulurken bu boyutlarla birlikte özellikle internet bağımlılı̆ıına ve siber zorbalığa da yer verilmiştir. Meclis araştırma komisyonu yazmış olduğu bu raporda eğitsel açıdan bakılması gerekliliği bağlamında, "İnternet bağımlılığı ve sorunlu internet kullanımının erken belirtilerinin aile veya okulda fark edilebilmesi amaciyla çalışmalar yapılması"; "internetin sorunlu kullanımına ilişkin ulusal düzeyde araşıırma yapılması" gibi önerilere de yer vermiştir.

TÜIK (2017b) raporunda bilgisayar ve internet kullanım oranlarının en yüksek olduğu yaş grubunun 06-15 arası grup olduğu belirtilmektedir. Bu araştırmada en yüksek kullanım oranlarının olduğu bu yaş grubundan daha düşük yaş gruplarına yönelerek internet bağımlılığı ve siber zorbalığın durumunun ortaokul çağında sorgulanması hedeflenmiştir. Ülkemizde yapılan araştırmaların ve meclis araştırma komisyonunun ortaya koyduğu sonuçlardan ve önerilerden hareketle bu araştırmanın problemi ortaokul çağındaki öğrencilerin internet bağımlılı̆̆ 1 ve siber zorbalık durumlarının bilinmemesi oluşturmuştur.

\section{Çalışmanın Amacı}

$\mathrm{Bu}$ araştırmanın amacı lise öğrencilerinin sanal ortamlarda hissettikleri risk algılarını bireysel düzeyde inceleyerek sanal dünyalarda "algılanan risk(tehdit/firsat)" konusunda yapılabilecek araştırmalara bir araç sunabilmek, sanal ortamlardaki risk algısını ölçebilen, likert tipi bir algı ölçeği geliştirmek ve lise öğrencileri bağlamında güvenirlik ve geçerliğini saptamaktır. Ayrıca geliştirilen Sanal Dünya Risk Algısı Ölçeği (SDRAÖ)'nin ilgili alanyazında sanal dünya ve sanal ortamlarla ilgili hangi boyutları ele aldığını tespit etmektir.

$\mathrm{Bu}$ çerçevede aşağıdaki soruya cevap aranacaktır:

- Lise öğrencilerinin sanal dünyada (sanal ortamlarda), -örneğin Facebook, Snapchat, Twitter, Instagram vb.var olan risklere ilişkin algılarını (sanal dünya risk algısı) belirleyebilmek amacıyla geliştirilen ölçek geçerli ve güvenilir bir ölçek midir?

\section{Yöntem}

\section{Araştırma Modeli}

Araştırmada Sanal Dünya Risk Algısı Ölçeği adı verilen ölçeği geliştirmek, geçerliğini ve güvenirliğini incelemek amacı ile likert tipi ölçek geliştirme yönteminden yararlanılmıştır. Gereksinim duyulan veriler, araştırmanın hedef kitlesi olarak tanımlanan çalışma grubundaki bireylerden ölçme aracı kullanılarak toplanmıştır.

\section{Evren ve Örneklem}

$\mathrm{Bu}$ araştırmanın evrenini Ağrı ili sınırları içerisindeki resmi ortaöğretim kurumları oluşturmaktadır. Çalışmada faktör analizi ve güvenirlik çalışmaları, Ağrı'da bulunan farklı liselerde (Meslek Lisesi, Teknik Lise, Anadolu Lisesi, İmam Hatip Lisesi) öğrenim gören 390 lise öğrencisinden elde edilen veriler ile gerçekleştirilmiştir (176 kız, 214 erkek). Uygulamada madde havuzunda 34 madde yer almaktadır. Ölçek çalışmalarında madde havuzunda yer alan madde sayısının 5 ila 10 katı kadar katılımcıya erişilmesi önerilir. Comrey ve Lee (1992), örneklem büyüklüklerinde 100 'ün zayıf düzey, 200'ün orta düzey, 300'ün iyi, 500'ün çok iyi ve 1000 'in ise mükemmel olduğunu nitelendirmiştir. Dolayısıyla uygulama için bu sayı yeterli görülmüştür. Bununla birlikte çalışma grubunda üst düzeyde çeşitlilik sağlamak amacıyla farklı alanlardaki okul öğrencilerine ulaşılması tercih edilmiştir. Bu öğrencilerin 63'ü (\%16.2) Meslek Lisesi, 252'si (\%64.2) Anadolu Lisesi ve 75'i (19.2) Teknik Lise öğrencisidir. Çalışma grupları oluşturulurken kolay örnekleme (convenience sampling) metodu uygulanmıştır. Çalışma grubunun okullara, sınıf düzeylerine ve cinsiyetlerine göre dağılımı Tablo 1'de özetlenmiştir. 
Tablo 1. Çalışma Grubunun Okul-Sınıf Düzeyi-Cinsiyet Dağılımı

\begin{tabular}{lcc}
\hline \hline Değişkenler & Frekans (n) & Yüzde (\%) \\
\hline Meslek Lisesi & 63 & $16.2 \%$ \\
Anadolu Lisesi & 252 & $64.6 \%$ \\
Teknik Lise & 75 & $19.2 \%$ \\
9. Sinıf & 120 & $30.8 \%$ \\
10. Sinıf & 136 & $34.9 \%$ \\
11. Sinıf & 76 & $19.5 \%$ \\
12. Sinıf & 58 & $14.9 \%$ \\
Kiz & 176 & $45.1 \%$ \\
Erkek & 214 & $54.9 \%$ \\
\hline \hline
\end{tabular}

\section{Veri Toplama Araçları-Verilerin Analiz Edilmesi}

Araştırmada veriler, araştırmacılar tarafından geliştirilen "Sanal Dünya Risk Algısı Ölçeği (SDRAÖ)" kullanılarak toplanmıştır. Ölçeğin geliştirilmesi sürecinde öncelikle ilgili yerli ve yabancı alanyazın taraması gerçekleştirilmiştir. Fakat daha önce sanal ortamlarda yer alan "risk" kavramını ölçen herhangi bir ölçme aracına rastlanmamıştır. İlgili literatür taraması neticesinde sanal dünyanın (sanal ortamların) karakteristik özellikleri belirlenmeye çalışılmıştır. Ölçeğin teorik çerçevesi teknolojinin kullanımında sanal ortamlarda var olan tehlike/tehdit ve fırsat/olanakları barındıran risk kavramı temele alınarak geliştirilmiştir. İncelemeler 1şığında yazılan verilerden 64 maddelik havuz oluşturulmuştur. Maddeler arasında ölçme aracının kullanılacağı hedef kitlenin özellikleri belirlenmiş ve yakın özellikleri ölçmeyi hedefleyen maddelerin gruplandırması yapılarak 40 maddelik taslak oluşturulmuştur. Kapsam geçerliğini sağlamak için taslak maddeler farklı üniversitelerde görev yapan Bilgisayar ve Öğretim Teknolojileri Eğitimi Bölümü ile Psikolojik Danışma ve Rehberlik Bölümü öğretim üyelerine sunularak uzman görüşü alınmış ve görüşler neticesinde 34 madde, lise öğrencilerinin sanal dünyaya ilişkin risk algılarını belirlemeye yönelik ölçek ifadeleri olarak belirlenmiştir. Ölçeğin görünüş geçerliği için Milli Eğitim Bakanlığı'nda Türkçe Öğretmeni olarak görev yapan bir uzman öğretmen tarafindan ölçekte yer alan maddelerin dilinin "anlaşılırlık" ve "gramer" açısından hedef kitle için uygunluğu tespit edilmiştir.

Ölçek maddelerinden 31 tanesi pozitif 3 tanesi negatif olacak şekilde sıra önemli olmaksızın ölçeğe uygulama için son hali verilmiştir. Daha sonra 10 kişilik küçük bir grupta ölçeğin pilot uygulaması yapılarak öğrencilerin sanal ortamların risk boyutunun kişi tarafından algılanmasına ilişkin görüşlerini 34 maddeden oluşan 5'li Likert tipi ölçeğe tanımlamaları istenmiştir. Öğrencilerin pozitif maddelere vermiş olduğu yanıtlar şu şekilde puanlanmıştır: Tamamen yansitıyor (5 puan), çok yansitıyor (4 puan), orta düzeyde yansitıyor (3 puan), az yansitıyor ( 2 puan) ve hiç yansıtmıyor (1 puan). Öğrencilerin negatif tasarlanan maddeler için vermiş oldukları yanıtlar ise ters puanlandırılmış ve istatistiksel analiz sürecinde ters kodlama yapılmıştır.

Ölçekten alınabilecek en düşük puan 34 iken en yüksek puan 170'tir. Alınan yüksek puanlar sanal dünyaya ilişkin risk alg1 düzeyinin de yüksek olduğunu göstermektedir. Son hali verilen ölçek çoğaltılarak 390 lise öğrencisine uygulanmıştır. Elde edilen veriler istatistiksel olarak ölçeğin geçerlik ve güvenirlik analizlerinin yapılması amacıyla SPSS 23.0 ve AMOS 24.0 programlarına uygun şekilde kodlanmıştır.

Toplanan veriler üzerinde ilk önce ölçeğin güvenirlik analizi gerçekleştirilmiştir. Güvenirlik katsayısı Cronbach alpha katsayısı $\alpha=0.88$ bulunmuştur. Ölçeğin güvenirlik değeri yüksektir, dolayısıyla ölçek geçerliliği için analiz yapmaya uygundur. Daha sonra ölçeğin yapı geçerliğini belirlemek için önce Kaiser-Meyer-Olkin (KMO) ve Bartlett analizleri gerçekleştirilerek faktör analizi yapılıp yapılmayacağı belirlenmiştir (Tavşancıl, 2006). KMO değerinin 90 üzerinde çıkması, veri setinin faktör analizi yapılması için mükemmel düzeyde olduğu şeklinde yorumlanmaktadır. Bunun yanında Bartlett testi değerlerine göre, sıfır hipotezinin 0.05 anlamlılık düzeyinde reddedildiği anlaşılmaktadır. Elde edilen değerler neticesinde veriler üzerinde açımlayıcı ve doğrulayııı faktör analizler yapılmış; ölçeğin faktörlere ayrılma durumu temel bileşenler analizi ile belirlenmiş; 
Faktör analizi, geliştirilen bir ölçekteki maddelerin daha az sayıda boyutlara ayırılıp ayrılmadığını tespit etmek amacıyla yapılır. Bu sebeple yapılan temel bileşenler analizi de faktörlere ayırma tekniği olarak kullanılan yöntemlerdendir. $\mathrm{Bu}$ bağlamda güvenirliğin yüksek oluşundan dolayı faktörler arasında ilişki olduğu düşünüldüğünden Promax eğik döndürme tekniği kullanılarak faktör yükleri incelenmiştir (Erkuş, 2003). Döndürme yöntemlerinden eğik (obligue) döndürme tekniği, faktörlerin birbiriyle ilişkili olduğu düşüncesi üzerine kurulur, dik (orthogonal) döndürmenin aksine eksenlerin döndürülmesinde farklı eksenler kullanılır. Promax döndürme sırasında (Kappa=4) faktör yükü .40'ın altındaki durumlar dikkate alınmamış, özdeğeri 1.00'den büyük faktörler değerlendirilmiş ve elde edilen sonuçlara göre analiz dışı tutulması gereken maddeler ölçekten çıkarılmış ve net değerler ile kesin sonuçlar alınana kadar faktör analizi çalışmaları tekrarlanmıştır (Çokluk, Şekercioğlu ve Büyüköztürk, 2010).

Promax döndürme yöntemi ile gerçekleştirilen Açımlayıcı Faktör Analizi sonucunda belirlenen 5 faktörlü yapının geçerliğini kanıtlamak ve gözlenen bu yapının veriler bağlamında ne derece uyumlu olduğunu belirlemek amacıyla aynı veri yapısı üzerinde Doğrulayıcı Faktör Analizi uygulanmıştır. DFA'da modelin geçerliğini değerlendirmek üzere Ki-kare uyum test (X2), yaklaşık hataların ortalama karekökü (RMSEA), karşılaştırmalı uyum indeksi (CFI), iyilik uyum indeksi (GFI), düzeltilmiş iyilik uyum indeksi (AGFI), Modelin temel hipoteziyle uyumluğu (NFI) ve standardize edilmiş uyum iyilik endeksi (SRMR) kullanılmıştır. Bu değerler için kabul edilebilir kriterlerin ise şu şekilde olduğu belirtilmektedir: Normlaştırılmış ki-kare olarak ifade edilen X2 / sd oranının 3'ün altında olması mükemmel uyumun göstergesi kabul edilmektedir (Yılmaz ve Çelik, 2009; Şimşek 2007). RMSEA ve SRMR değerlerinin .05 'ten küçük veya eşit olması iyi bir uyumu, .05 ile .08 arasında olması ise yeterli uyumu göstermektedir (Yılmaz ve Çelik, 2009; Şimşek 2007). GFI ve CFI değerlerinin .90 üstünde, AGFI değerinin ise $.85^{\prime}$ ten daha büyük olması kabul edilir uyumun göstergesi olarak kabul edilmektedir (Yılmaz ve Çelik, 2009). Tüm analizler sonucunda elde edilen 5 faktör ve 26 maddelik ölçeğin güvenirliği Cronbach Alpha, Guttmann Split Half ve Sperman Brown güvenirlik katsayılarına göre incelenmiştir.

\section{Bulgular}

Sanal Dünya Risk Algısı Ölçeği (SDRAÖ)'nin geçerliği çerçevesinde yapı geçerliği, madde-toplam korelasyonları ve madde ayırt edicilikleri incelenmiş; güvenirlik bağlamında ise veriler üzerinde iç tutarlılık katsayısı Cronbach alpha değerine bakılmış ve yapılan işlemler ile elde edilen bulgular aşağıda sunulmuștur:

\section{Ölçek Geçerliğine İliş̧kin Bulgular}

Ölçeğin yapı geçerliği faktör analizi, madde toplam korelasyonları ve madde ayırt ediciliklerine bakılarak incelenmiştir. Tavşancıl (2002)'a göre ölçekte yer alan maddeler için madde test korelasyonlarının .30 ve üzeriden olması uygun görülmektedir. Bununla birlikte maddelerin birden fazla faktörle binişik olmaması da göz önünde tutularak işlemler gerçekleştirilmelidir. Birden fazla faktörle binişik olması durumuna ilişkin ölçüt, faktör yükleri arasında en az .10 fark olmasıdır. Chi-Hwang ve Henry (1990), Yavuz (2005) ve Tsai ve Chai (2005) yapmış oldukları çalışmalarda faktör yüklerinin $.40^{\prime}$ ’n altında olan maddeleri ölçekten çıkarmış. Bununla birlikte Büyüköztürk (2007) faktör yüklerinin .45 ’ten büyük olmasının ölçek maddelerinin seçimi için önemli bir ölçüt olacağını ifade etmiştir. Bu sebeple bu araştırmada madde toplam korelasyonları .30'un altındaki maddeler ve faktör yük değerleri .40'ın altında olan maddeler ile binişik olan maddeler arasında .10 'dan az fark olan maddeler ölçekten çıkarılacaktır kanısı baz alınmıştır.

\section{Açımlayıcı faktör analizi sonuçları:}

SDRAÖ'nin yapı geçerliğini test etmek için veriler üzerinde öncelikle KMO ve Bartlett testleri yapılmış ve $\mathrm{KMO}=.922$; Bartlett değeri ise $\mathrm{X} 2=4627,412 ; \mathrm{sd}=561(\mathrm{p}=.000)$ olarak tespit edilmiştir. Elde edilen bu değerler neticesinde, 34 maddelik ölçek üzerinde faktör analizi yapılabileceğini ve verilerin çok değişkenli normal dağılımdan geldiğini kanıtlamaktadır. Ölçekteki binişik maddelerin tespiti ve faktör yük değeri .40'ın altında olan maddelerin elenmesi için ölçek üzerinde 4 kez faktör analizi gerçekleştirilmiştir. Bu süreçte uygulanan aşamaların içeriği şu şekildedir: Birinci faktör analizi aşamasında, Promax eğik döndürme tekniği kullanılarak yapılan temel bileşenler faktör analizi işlemi neticesinde özdeğerleri 1'den büyük olan 7 faktör elde edilmiştir. Bu 7 faktör toplam varyansın \% 54.72'sini açıklamaktadır. Bu aşamada yer alan 34 maddenin madde toplam korelasyon değerleri .30 ile .70 arasındadır. 9, 12, 15 ve 16. Maddelerin faktör yük değerleri .40 'ın altında kaldığından dolayı ölçekten çıkarılmışıır. 27. maddenin de binişik madde olması nedeniyle ölçekten çıkarılması tespit edilmiştir. Kalan 29 madde üzerinde 2. Faktör analizi uygulanmıştır. İkinci faktör analizi sonuçlarına göre ölçek özdeğeri 1'den büyük 
olan 6 faktör alınta toplanmış olup bu 6 faktör toplam varyansın \% 50.06'sını açıklamaktadır. Ikinci aşamadaki maddelerin toplam madde korelasyonları ,30 ile ,61 arasında yer almaktadır. Bu aşamada yine .40'ın altında faktör yük değerine sahip 18, 20 ve 30. Maddeler bir sonraki analize dahil edilmemiştir. Üçüncü faktör analizi sonuçlarına göre ise, ölçek özdeğeri 1'den büyük olan 5 faktör altında toplanmıştır. Bu 5 faktör toplam varyansın \%51.72'sini açıklamaktadır. Bu aşamada madde toplam korelasyonları .30 ile .58 arasında tespit edilmiştir.

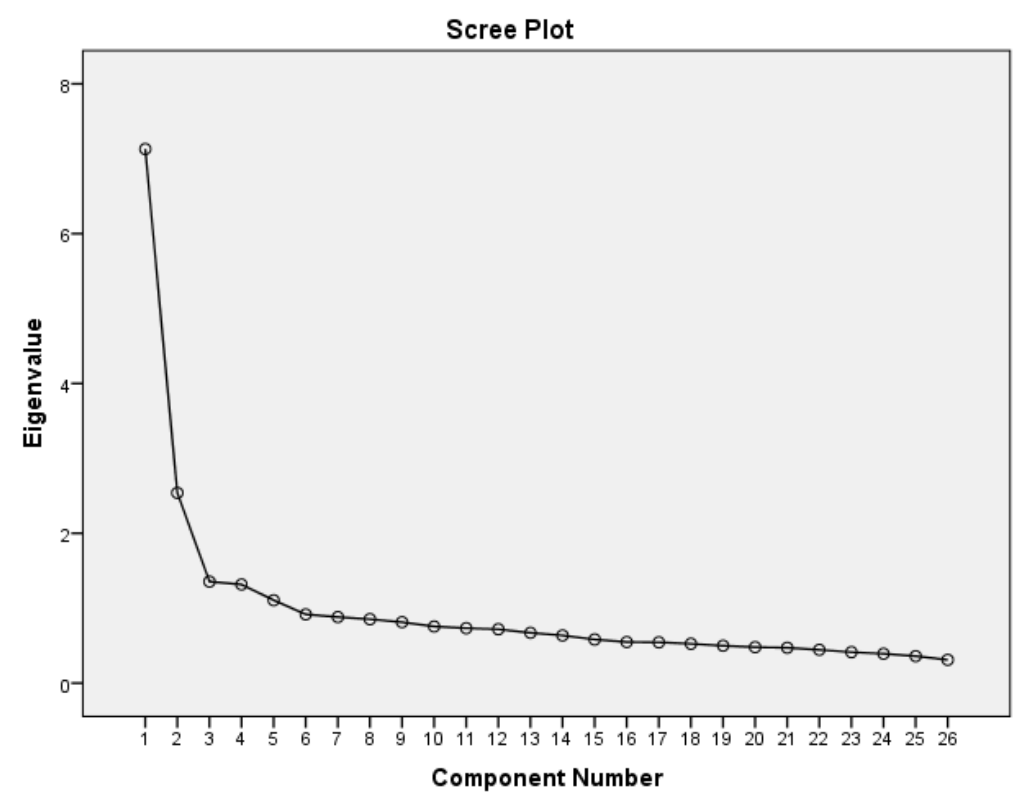

Şekil 1. Özdeğerlere ait çizgi grafiği

Şekil 1'de yer alan özdeğerlere ait çizgi grafiğinde de görüldüğü üzere ölçeğin 5 faktör altında toplandığ özdeğerlere ait çizgi grafiğinden de anlaşılmaktadır. Grafikte, birinci faktörden sonra yüksek ivmeli bir düşüşün görülmesi ölçeğin genel bir faktöre sahip olduğunu göstermektedir. Beşinci faktörden sonra grafiğin genel gidişatı yatay olup, önemli bir düşüş eğilimi gözlenmemektedir.

Tablo 2. Çalışma Grubunun Okul-Sınıf Düzeyi-Cinsiyet Dağılımı

\begin{tabular}{|c|c|c|c|c|c|c|c|c|}
\hline \multirow{2}{*}{$\begin{array}{c}\text { Madde } \\
\text { No }\end{array}$} & \multirow{2}{*}{$\begin{array}{c}\text { Yeni } \\
\text { Sira No }\end{array}$} & \multirow{2}{*}{$\begin{array}{c}\text { Faktör } \\
\text { Yük } \\
\text { Değeri }\end{array}$} & \multicolumn{5}{|c|}{ Döndürülmüş Faktör Yük Değerleri } & \multirow{2}{*}{$\begin{array}{c}\text { Madde } \\
\text { Toplam } \\
\text { Korelasyon } \\
\text { Değerleri } \\
\end{array}$} \\
\hline & & & Faktör 1 & Faktör 2 & Faktör 3 & Faktör 4 & Faktör 5 & \\
\hline Md7 & 1 & .705 & .763 & & & & & .490 \\
\hline $\mathrm{Md} 2$ & 2 & .660 & .743 & & & & & .489 \\
\hline Md6 & 3 & .697 & .662 & & & & & .477 \\
\hline Md3 & 4 & .527 & .639 & & & & & .383 \\
\hline Md8 & 5 & .733 & .582 & & & & & .535 \\
\hline Md1 & 6 & .546 & .537 & & & & & .449 \\
\hline Md5 & 7 & .552 & -.501 & & & & & .497 \\
\hline $\operatorname{Md} 32$ & 8 & .606 & & .796 & & & & .459 \\
\hline Md33 & 9 & .614 & & .756 & & & & .477 \\
\hline $\operatorname{Md} 28$ & 10 & .643 & & .627 & & & & .543 \\
\hline $\operatorname{Md} 17$ & 11 & .707 & & .550 & & & & .589 \\
\hline
\end{tabular}




\begin{tabular}{|c|c|c|c|c|c|c|c|c|}
\hline $\operatorname{Md} 21$ & 12 & .654 & & .536 & & & & .510 \\
\hline $\operatorname{Md} 22$ & 13 & .591 & & .432 & & & & .485 \\
\hline Md34 & 14 & .575 & & & .783 & & & .395 \\
\hline $\operatorname{Md} 26$ & 15 & .639 & & & .726 & & & .403 \\
\hline $\operatorname{Md} 25$ & 16 & .665 & & & .627 & & & .428 \\
\hline $\mathrm{Md} 24$ & 17 & .485 & & & .495 & & & .428 \\
\hline Md10 & 18 & .546 & & & & -.842 & & .407 \\
\hline Md11 & 19 & .536 & & & & .629 & & .403 \\
\hline Md4 & 20 & .350 & & & & -.507 & & .306 \\
\hline $\operatorname{Md} 29$ & 21 & .694 & & & & .492 & & .461 \\
\hline Md31 & 22 & .613 & & & & .472 & & .391 \\
\hline $\operatorname{Md} 23$ & 23 & .591 & & & & & .693 & .417 \\
\hline $\operatorname{Md} 13$ & 24 & .483 & & & & & .580 & .402 \\
\hline Md19 & 25 & .580 & & & & & .571 & .327 \\
\hline $\operatorname{Md} 14$ & 26 & .533 & & & & & .483 & .355 \\
\hline \multicolumn{3}{|c|}{ Özdeğerler } & 7.130 & 2.539 & 1.355 & 1.316 & 1.107 & \\
\hline \multicolumn{3}{|c|}{ Açıklanan Varyans Oranı } & 27.423 & 9.767 & 5.212 & 5.062 & 4.257 & \\
\hline \multicolumn{3}{|c|}{$\begin{array}{c}\text { Ölçek için açıklanan toplam } \\
\text { varyans oranı }\end{array}$} & \multicolumn{6}{|c|}{51.721} \\
\hline \multicolumn{3}{|c|}{ Cronbach Alpha } & $\alpha=.63$ & $\alpha=.80$ & $\alpha=.68$ & $\alpha=.69$ & $\alpha=.63$ & \\
\hline \multicolumn{3}{|c|}{ Tüm ölçek için Cronbach Alpha } & \multicolumn{6}{|c|}{$\alpha=.82$} \\
\hline
\end{tabular}

Tablo 2'de görüldüğü üzere nihai ölçekteki 5 faktör ölçek varyansının \%51.72'sini açıkmaktadır. Ölçeğin madde korelasyonu ise .33 ile .59 arasında görülmektedir. Ölçekte binişik madde bulunmamaktadır. Faktör yük değerleri ise .40 ile .61 arasında değişmektedir. 26 maddelik ölçek EK 1'de yer almaktadır. Faktör adlandırmaları ise literatür incelemesi neticesinde belirlenmiştir. 1. Faktör maddeleri "Sanal Yozlaşma", 2. Faktör maddeleri "Sanal Yıpranma", 3. Faktör maddeleri "Sanal Olanak", 4. Faktör maddeleri "Sanal Fursat" ve 5. Faktör maddeleri "Sanal Farkındalık" olarak isimlendirilmiştir.

\section{Doğrulayıcı faktör analizi sonuçları}

Doğrulayıcı faktör analizi (DFA) (Confirmatory Factor Analysis: CFA), ölçme modellerinin geliştirilmesinde sıkça başvurulan bir analiz yöntemidir. Bu yöntem sayesinde, önceden oluşturulmuş bir model aracılığıyla Açımlayıcı Faktör Analizi (AFA) (Explanatory Factor Analysis: EFA) ile belirlenmiş faktörlerin belirlenen faktör yapılarına uygunluğunu test etmede yararlanılan faktör analizidir. AFA, hangi madde gruplarının hangi faktör ile yüksek düzeyde bağlantılı olduğunu test ederken, belirlenen sayıda faktörle ilişkili madde gruplarının bu faktörler ile yeterince temsil edilip edilmediğinin belirlenmesi bağlamında DFA'dan yararlanılır.

Bu bağlamda maksimum olasılık tekniği kullanılarak yapılan doğrulayıcı faktör analizi sonucunda uyum iyiliği değerleri; Ki Kare / Serbestlik Derecesi $(\mathrm{CMIN} / \mathrm{DF})=2.047, \mathrm{X} 2=591.496, \mathrm{p}<.000$, RMSEA $=.052, \mathrm{~S}-\mathrm{RMR}=$ $.124, \mathrm{GFI}=.90, \mathrm{AGFI}=.88, \mathrm{CFI}=.89, \mathrm{NFI}=.81$ ve $\mathrm{IFI}=.90$ olarak bulunmuştur. Bu değerlere göre tüm iyilik değerlerinin kabul edilebilir değerler olduğu söylenebilir (Munro, 2005; Schreiber, Nora, Stage, Barlow and King, 2006). Dolayısıyla bu model, veriler tarafından faktörlerin doğrulandığını ifade etmektedir. Ölçeğin faktöriyel modeli ve faktör madde ilişkisini gösteren t değerleri Şekil 2'de verilmiştir. 


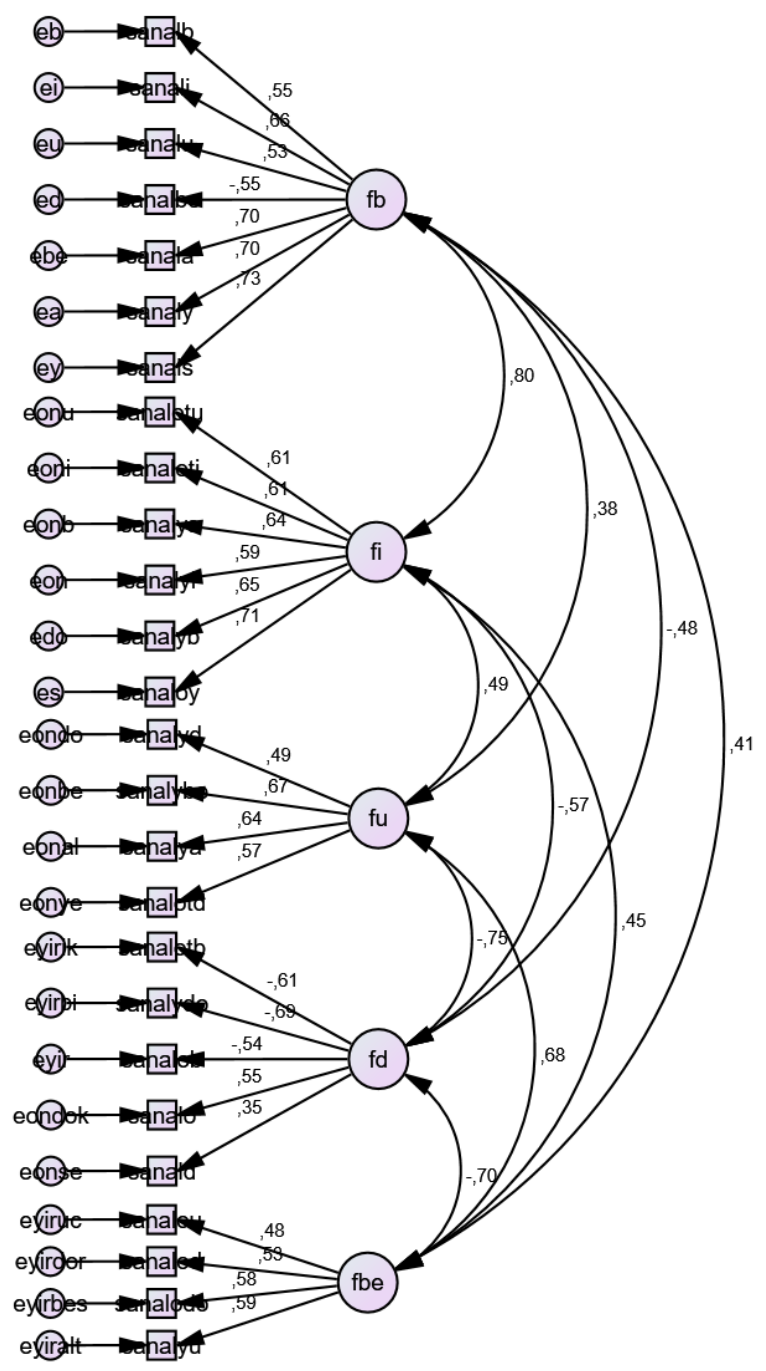

Şekil 2. Birinci düzey doğrulayıcı faktör analizi korelasyon diyagramı (Standardize edilmiş değerler)

\section{Ölçek Güvenirliğine İlişskin Bulgular}

Ölçeğin güvenirliğini hesaplamak üzere veriler üzerinde iç tutarlılık analizi gerçekleştirilmiştir. Yapılan işlemler ve bulgular aşağıda yer almaktadır.

Ölçeğin faktörlere göre ve bütün olarak güvenirliği; Cronbach alpha, Sperman-Brown formülü ve Guttmann Split-Half güvenirlik formülleri ile hesaplanmıştır. Faktörlere ve ölçeğin tamamına ilişkin güvenirlik analiz sonuçları Tablo 3’te verilmiştir:

Tablo 3. İç tutarlılık düzeyleri

\begin{tabular}{lcccc}
\hline Faktörler & $\begin{array}{c}\text { Madde } \\
\text { Sayıları }\end{array}$ & $\begin{array}{c}\text { Cronbach } \\
\text { Alpha }\end{array}$ & $\begin{array}{c}\text { Sperman } \\
\text { Brown }\end{array}$ & $\begin{array}{c}\text { Guttmann } \\
\text { Split Half }\end{array}$ \\
\hline $\begin{array}{l}\text { F1 - Sanal } \\
\text { Yozlaşma }\end{array}$ & 7 & .63 & .66 & .65 \\
\hline $\begin{array}{l}\text { F2 - Sanal } \\
\text { Yıpranma }\end{array}$ & 6 & .80 & .76 & .75 \\
\hline
\end{tabular}




\begin{tabular}{lcccc}
\hline $\begin{array}{l}\text { F3 - Sanal } \\
\text { Olanak }\end{array}$ & 4 & .68 & .67 & .67 \\
\hline $\begin{array}{l}\text { F4 - Sanal } \\
\text { Firsat }\end{array}$ & 5 & .69 & .57 & .56 \\
\hline $\begin{array}{l}\text { F5 - Sanal } \\
\text { Farkındalık }\end{array}$ & 4 & .63 & .64 & .64 \\
\hline Toplam & $\mathbf{2 6}$ & $\mathbf{. 8 2}$ &. $\mathbf{7 2}$ & $\mathbf{. 8 6}$ \\
\hline
\end{tabular}

\section{Tartışma ve Sonuç}

$\mathrm{Bu}$ araştırmada özellikle Facebook, Instagram, Twitter vb. Sanal ortamlarda var olan risk düzeylerini belirlemek üzere Sanal Dünya Risk Algısı Ölçeği (SDRAÖ) geliştirilmiştir. Geliştirilen SDRAÖ beşli likert tipi bir ölçek olup 5 faktör altında şekillenen 26 maddeden oluşmaktadır. Faktörlerde yer alan maddeler; "Tamamen yansitıyor", "Çok yansitıyor", "Orta düzeyde yansıtıyor", "Az yansıtıyor" ve "Hiç yansıtmıyor" ifadeleri ile bireyin ölçekte yer alan maddelerin kendi algısını ne düzeyde yansıttığını ortaya koyacağı şekilde ölçeklendirilmiş̧tir. 9-12. Sınıflarda öğrenim gören 390 öğrenciye uygulanmıştır.

Ölçeğin geçerlik çalışmaları kapsamında faktör analizi yapılmıştır. KMO ve Bartlett testleri değerlerine göre $(\mathrm{KMO}=.922$, Bartlett=3099,284, p=.000) ölçek çalışması üzerinde faktör analizi yapılması uygun görülmüştür. İlk olarak Açımlayıcı Faktör Analizi (AFA) ile ölçeğin kaç faktöre ayrıldığı, faktörlerin varyansın \%40'ından fazlasını açıklayıp açıklamadığı ve hangi yüklerle hangi faktörlere dağılım yapıldığı test edilmiştir. Bu bağlamda Principal component ile özütü alınarak, -güvenirlik yüksek görüldüğünden- döndürme tekniklerinden promax $(k a p p a=4)$ eğik döndürme tekniği kullanılmıştır. AFA neticesinde ölçeğin 5 faktöre ayrıldığı ve faktörlerin tüm varyansın \%51.72'sini açıklayabildiği görülmüştür. Faktör yükleri ile dağılım tespit edilirken eşik değerin .40'ın üzerinde olması benimsenmiştir. AFA'dan sonra gerçekleştirilen Doğrulayıcı Faktör Analizi neticesinde ise, dağıtımı yapılan faktör maddelerinin AFA'yı desteklediği, DFA değerlerinin (X2/sd, p, RMSEA, S-RMR, GFI, AGFI, CFI, NFI, IFI) yüksek ölçütlerde sağlandığı tespit edilmiş ve faktör isimlendirmeleri ilgili alanyazın bağlamında yapılmıştır. Kapsam geçerliği ve görünüş geçerliğinin sağlanması adına, ölçek henüz geliştirme aşamasında iken farklı alan uzmanlarına sunularak alınan görüşler doğrultusunda gerekli düzenlemeler yapılarak kapsam, görünüş ve dil geçerliği sağlanmıştır. Bu sonuçlar SDRAÖ’nin geçerliğinin olduğuna işaret etmektedir.

SDRAÖ'nin iç tutarlılık anlamındaki güvenirlikleri Cronbach Alpha, Guttmann Split Half ve Sperman Brown güvenirlik katsayıları hesaplanarak incelenmiş̧ir. Birleşik ölçeğin Cronbach Alpha, Guttmann Split Half ve Sperman Brown güvenirlik katsayıları sırasıyla, $.82, .72$ ve .86 olarak hesaplanmış ve güvenirlik düzeylerinin oldukça iyi düzeyde olduğu sonucuna varılmıştır.

Çalışmadan elde edilen bu sonuçlara yönelik olarak geliştirilen öneriler aşağıda sunulmuştur.

- Sanal Dünya Risk Algısı Ölçeği (SDRAÖ), birleşik ölçek ve 5 alt boyutu ile geçerli ve güvenilir puanlar verebilöektedir. Bu nedenle, birleşik ölçek puanları ile lise öğrenimi gören öğrencilerin genel olarak sanal dünyaya ilişkin risk algı düzeylerinin ölçülmesi amacıyla kullanılabilir. Bunun yanında alt faktör puanları ile lise öğrencilerinin "sanal yozlaşma", "sanal yıpranma", "sanal olanak", "sanal firsat" ve "sanal farkındalık" düzeylerine ilişkin algılar ölçülebilir.

- Ölçek, liselerde öğrenim gören öğrenciler üzerinde çalışllarak geliştirilmiştir. Ölçeğin ortaokul ya da üniversite seviyelerinde de kullanılabilmesi amacıyla bu kademelerdeki öğrenciler üzerinde çalışılması düşünülebilir.

- Bu çalışmada yapılmamış olan, test tekrar test güvenirliği ve madde ayırt edicilikleri üzerinde çalışabilir.

- Bu sonuçlara bağlı olarak araştırmacıların, okul idarelerinin, öğretmenlerin görev yapmış oldukları liselerdeki öğrencilerin sanal dünyaya ilişkin risk algılarının ne boyutlarda hangi etmenlere bağlı olduğunu ve sanal risk algılarına karşı önlemler alınması amacıyla çalışmalarda SDRAÖ’ni kullanmaları önerilebilir. 


\section{References}

Arıcak, O.T. (2009). Psychiatric symptomatology as a predictor of cyberbullying among university students. Eğitim Araştırmalarl-Eurasian Journal of Educational Research, 34, ss.167-184.

Ayas, T. (2012). Lise öğrencilerinin internet ve bilgisayar oyun bağımlılık düzeylerinin utangaçlıkla ilişkisi. Kuram ve Uygulamada Ĕgitim Bilimleri, 12(2), 627-636.

Baker Erdur, Ö. ve Kavşut, F. (2007). Cyber bullying: A new face of peer bullying. Eğitim Araştırmaları-Eurasian Journal of Educational Research, 27, 31-42.

Bilge, F. (2012). Bir grup ilköğretim öğrencisinde bilgisayara yönelik bağımlılık eğilimi değerlendirmesi. Hacettepe Üniversitesi Eğitim Fakültesi Dergisi, 43, 96-105

Büyüköztürk, Ş.(2007). Sosyal bilimler için veri analizi el kitabı, Ankara: Pegem A Yayıncılık.

Ceyhan, A.A. (2011). Ergenlerin problemli internet kullanım düzeylerinin yordayıcıları. Çocuk ve Gençlik Ruh Sağlığ1 Dergisi, 18(2), 85-94.

Comrey, A.L \& Lee, H.L.(1992). A first course in factor analysis, Hillsdale, New Jersey: Erlbaum.

Çetin, B.; Eroğlu, Y.; Peker, A.; Akbaba, S. ve Pepsoy, S. (2012). Lise Öğrencilerinin Siber-Zorbalığa İlişkin Görüşlerinin Bazı Değişkenler Bakımından İncelenmesi. Kuram ve Uygulamada Eğitim Bilimleri, 12(2), ss.637-653.

Çokluk, Ö., Şekercioğlu, G. ve Büyüköztürk, Ş. (2012). Sosyal Bilimler İçin Çok Değişkenli İstatistik: SPSS ve Lisrel Uygulamaları, Pegem Akademi Yayınc1lık, Ankara.

Ekşi, F. (2012). Narsistik kişilik özeliklerinin internet bağımlılı̆̆ı ve siber zorbalığı yordama düzeyinin yol analizi ile incelenmesi. Kuram ve Uygulamada Eğitim Bilimleri, 12(3), 1683-1706.

Erkuş, A. (2003). Psikometri Üzerine Yazılar. Ankara: Türk Psikologlar Derneği Yayınları

Hwang, C \& Henry, L. (1990). Development and validation of the mathematics anxiety scale for children, Measurement and Evaluation in Counseling and Development, 23(3), 121-127.

Munro BH. Statistical Methods For Health Care Research. Philadelphia: Lippincott Williams \& Wilkins; 2005. p.351-76

Özdemir, M. ve Akar, F. (2011). Lise öğrencilerinin siber-zorbalığa ilişkin görüşlerinin bazı değişkenler bakımından incelenmesi. Kuram ve Uygulamada Eğitim Yönetimi, 17(4), ss.605-626.

Schreiber JB, Nora A, Stage FK, Barlow EA, King J. Reporting Structural Equation Modeling and Confirmatory Factor Analysis Results: A Review. The Journal of Educational Research 2006; 99(6): 323-38.

Şimşek, Ö. F. (2007). Yapısal Eşitlik Modellemesine Giriş: Temel İlkeler ve LISREL Uygulamaları. Ankara: Elinoks Yayıncılık.

TBMM (2012). Bilgi toplumu olma yolunda bilişim sektöründeki gelişmeler ile internet kullanımının başta çocuklar gençler ve aile yapısında olmak üzere sosyal etkilerinin araştırılması amacıyla kurulan meclis araştırma komisyonu raporu. TBMM Dönem 24, Yasama yılı 2.

Tsai, L.S\& Chai, K.S (2005), Developing and validating a nursing website evaluation questionnaire, Methodological Issues in Nursing Research, 49(4), 416-413.

TÜİK (2017a). Hanehalkı Bilişim Teknolojileri Kullanım Araştırması-2017.

TÜİK (2017b). 06-15 Yaş Grubu Çocuklarda Bilişim Teknolojileri Kullanımı Ve Medya-2017.

Yaman, E. ve Peker, A. (2012). Ergenlerin siber zorbalık ve siber mağduriyete ilişkin algıları. Gaziantep Üniversitesi Sosyal Bilimler Dergisi, 11(3), ss.819-833.

Yavuz, S.(2005), Developing a technology attitude scale for pre service chemistry teachers, The Turkish Online Journal of Educational Technology, 4(1). 
Yılmaz, V. , Çelik, H. E. (2009). LISREL ile Yapısal Eşitlik Modellemesi I: Temel Kavramlar, Uygulamalar, Programlama. Ankara: Pegem Akademi. 


\section{EK1. Sanal Dünya Risk Algısı Ölçeği (SDRAÖ)}

\begin{tabular}{|c|c|c|c|c|c|}
\hline SANAL DÜNYA RİSK ALGISI ÖLÇEĞİ & $\begin{array}{l}\text { Tamamen } \\
\text { yansitiyor }\end{array}$ & $\begin{array}{l}\text { Çok } \\
\text { yansitıyor }\end{array}$ & $\begin{array}{l}\text { Orta Düzeyde } \\
\text { yansitıyor }\end{array}$ & $\begin{array}{l}\text { Az } \\
\text { yansitiyor }\end{array}$ & $\begin{array}{l}\text { Hiç } \\
\text { yansitmıyor }\end{array}$ \\
\hline \multicolumn{6}{|l|}{$\begin{array}{l}\text { 1. Sanal ortamlarda karşılasştığım bireyleri olduğundan farklı } \\
\text { tanıyarak onlar tarafından kandırılabilirim }\end{array}$} \\
\hline \multicolumn{6}{|l|}{$\begin{array}{l}\text { 2. Sanal ortamlara olan bağl1lığım artarsa gerçek yaşamda } \\
\text { samimi sohbetlerden kendimi soyutlayıp uzaklaşabilirim. }\end{array}$} \\
\hline \multicolumn{6}{|l|}{$\begin{array}{l}\text { 3. Yaşadığım sorun ve sıkıntıları istemeden de olsa, } \\
\text { tanımadığım insanlarla paylaşmak durumunda kalabilirim. }\end{array}$} \\
\hline \multicolumn{6}{|l|}{$\begin{array}{l}\text { 4. Hiç tanımadığım insanlarla sohbet ederken kendimi rahat } \\
\text { hissederim. }\end{array}$} \\
\hline \multicolumn{6}{|l|}{$\begin{array}{l}\text { 5. Sanal ortamlardayken gerçek hayat sorunlarından } \\
\text { uzaklaşabilirim. }\end{array}$} \\
\hline \multicolumn{6}{|l|}{$\begin{array}{l}\text { 6. Sanal ortamlara olan bağlılığım artarsa kendini olduğumdan } \\
\text { farklı bir karakterle yansıtabileceğimden dolayı kimlik çatışması } \\
\text { yaşayacağım hissine kapılabilirim. }\end{array}$} \\
\hline \multicolumn{6}{|l|}{$\begin{array}{l}\text { 7. Uzun süre sanal ortamlarla iç içe olduğum taktirde psikolojik } \\
\text { rahatsızlıklar yaşayabilirim. }\end{array}$} \\
\hline \multicolumn{6}{|l|}{$\begin{array}{l}\text { 8. Yaptığım sanal sohbetlerde, özümde var olan evrensel } \\
\text { kurallar (doğruluk, dürüstlük gibi) önemini kaybedebilir. }\end{array}$} \\
\hline \multicolumn{6}{|l|}{ 9. Sanal ortamlardaki kişiler bana yakın gelebilir. } \\
\hline \multicolumn{6}{|l|}{$\begin{array}{l}\text { 10. Sanal ortamlarda paylaştığım düşünce ve fikirlerimi } \\
\text { birilerinin mutlaka göreceğini bilmek beni piskolojik açıdan } \\
\text { rahatlatabilir. }\end{array}$} \\
\hline \multicolumn{6}{|l|}{$\begin{array}{l}\text { 11. Sanal dünyada çok fazla vakit kaybetmem neticesinde } \\
\text { derslerimde başarısız sonuçlarla karşılaşabilirim. }\end{array}$} \\
\hline \multicolumn{6}{|l|}{$\begin{array}{l}\text { 12. Sanal ortamlarda bilgiye erişim kolay olduğu için zamandan } \\
\text { tasarruf edebilirim. }\end{array}$} \\
\hline \multicolumn{6}{|l|}{$\begin{array}{l}\text { 13. Sanal alemde sürekli yayınlanan reklamların bilinçaltıma yer } \\
\text { etmesi ile marka bağımlısı bir birey haline dönüşebilirim. }\end{array}$} \\
\hline \multicolumn{6}{|l|}{ 14. Sanal ortamlar sayesinde eski arkadaşlarımı bulabilirim } \\
\hline \multicolumn{6}{|l|}{$\begin{array}{l}\text { 15. Yapılacak sınırsız sohbetler neticesinde mahremiyet, gizlilik, } \\
\text { utanma gibi duygularımı yitirebilirim. }\end{array}$} \\
\hline \multicolumn{6}{|c|}{$\begin{array}{l}\text { 16. Sanal ortamlarda her şeye kolayca erişebilmem neticesinde } \\
\text { gerçek hayattaki engellere karşı mücadelen uzak bir hale } \\
\text { gelebilirim. }\end{array}$} \\
\hline \multicolumn{6}{|l|}{$\begin{array}{l}\text { 17. Sanal ortamlara ayıracağım süreyi iyi planlayabildiğim taktirde } \\
\text { kontrol açısından bireysel gelişim katk1 sağlayabilirim. }\end{array}$} \\
\hline \multicolumn{6}{|l|}{ 18. Sanal ortamlarda tartışmak beni rahatlatır. } \\
\hline \multicolumn{6}{|l|}{$\begin{array}{l}\text { 19. Sanal medyayı aktif kullanarak yardımlaşma-dayanışma } \\
\text { kültürümü geliştirebilirim. }\end{array}$} \\
\hline \multicolumn{6}{|l|}{$\begin{array}{l}\text { 20. Sosyal medya sayesinde araştırma kapasitemi kullanarak } \\
\text { eleştirel düşünme becerimi geliştirebilirim. }\end{array}$} \\
\hline \multicolumn{6}{|l|}{ 21. Sosyal medya yüzünden dedikodu kültürüne kapılabilirim. } \\
\hline \multicolumn{6}{|l|}{$\begin{array}{l}\text { 22. Kuracağım sanal arkadaşlıklar sayesinde yeni kültürler } \\
\text { tanıyabilirim. }\end{array}$} \\
\hline \multicolumn{6}{|l|}{ 23. Sosyal medya aracılığg ile yeni dostluklar edinebilirim. } \\
\hline \multicolumn{6}{|l|}{$\begin{array}{l}\text { 24. Sanal ortamların olumsuz yönleri neticesinde sorumsuz bir } \\
\text { kişilik haline dönüşebilirim. }\end{array}$} \\
\hline \multicolumn{6}{|l|}{$\begin{array}{l}\text { 25. Sosyal medyada bilinçsizce sörf eden insanlar yüzünden } \\
\text { manevi yıpranmalar yaşabilirim. }\end{array}$} \\
\hline $\begin{array}{l}\text { 26. Sanal ortamlar aracılığı ile problem çözme becerisi } \\
\text { kazanabilirim. }\end{array}$ & & & & & \\
\hline
\end{tabular}

NOT: Yazarlardan e-posta yoluyla izin alınmak kaydıyla ölçek her türlü bilimsel çalışmalarda kullanılabilir. vbilalarslankara@gmail.com, ertugrulusta@gmail.com 